\title{
China's Agricultural Support Capacity and Dependence on Foreign Resources
}

\author{
Yan Zhang, Xiaohui Yang*, Hong Zhang, Li Ma \\ School of Geographic and Oceanographic Sciences, Nanjing University, Nanjing, China \\ Email: zhangynju@sina.com, ${ }^{\star}$ yangxiaohuiqufu@163.com, zhhongnju@nju.edu.cn,362221382@qq.com
}

How to cite this paper: Zhang, Y., Yang, X.H., Zhang, H. and Ma, L. (2018) China's Agricultural Support Capacity and Dependence on Foreign Resources. Food and Nutrition Sciences, 9, 1-19. https://doi.org/10.4236/fns.2018.91001

Received: November 8, 2017

Accepted: January 14, 2018

Published: January 17, 2018

Copyright ( $) 2018$ by authors and Scientific Research Publishing Inc. This work is licensed under the Creative Commons Attribution International License (CC BY 4.0).

http://creativecommons.org/licenses/by/4.0/

(c) (i) Open Access

\begin{abstract}
To more accurately answer the questions "who will feed China?" and "whether Chinese people can feed themselves?", we proposed a concept of agricultural support capacity, defined as the population that can be fed by energy, protein and fat from food, respectively, according to nutritional intake standards. In this study, we established models to measure this, based on analysis of China's agricultural support capacity and how this changes under self-sufficiency and open conditions, in addition to the degrees of external dependence. Our results show that, since 2007, even without foreign resources, the energy, protein, superior protein and fat obtained from domestic agriculture had been able to feed the Chinese. However, the use of foreign resources increased and strengthened China's agricultural support capacity, in addition to improving food diversity, optimizing nutrition, assisting in the regulation of food surplus and deficiency, and providing feed for the animal breeding industry. For the past decade, China's degree of external dependence on energy from cereals has been relatively low, however, the degrees external dependence on superior protein and fat has increased steadily at a certain rate and have been over the national food security warning level. Therefore, China still has great demand for agricultural products from other regions of the world.
\end{abstract}

\section{Keywords}

Agricultural Products, Support Capacity, Energy, Nutrients, Degree of External Dependence

\section{Introduction}

The basic function of agriculture is to feed people. Since Lester R. Brown [1] first asked "who will feed China?", whether or not China's agriculture can feed the Chinese people has become a highly discussed topic. Research on this topic has 
mainly focused on China's food security. Since then, the government of China has released white paper titled on "food issue in China" [2] and "national food security and long-term planning framework (2008-2020)" [3]. Although the spatial and temporal scales are different, academic research in this field has mainly focused on potential crop productivity and the impact of loss of arable land on China's food security, from the perspective of agriculture production [4] [5] [6] [7], or on China's food demand from the perspective of consumption, trade and nutrition [8]-[15]. Chen and Zhou [16] established a safe baseline of cultivated land based on the comprehensive production capacity of agricultural resources. Rask and Rask [17] [18] analyzed changes in food production and consumption along with economic development, using resource-based cereal-equivalent measures. Moreover, many studies have discussed the self-sufficiency rate of a single agricultural product, such as wheat, rich, oilseed crops, etc. [19] [20] [21], but have not considered a substitution effect among different kinds of agricultural products. Few studies have reported on China's degree of external dependence on agricultural support capacity, which have been comprehensively measured as the population that can be fed by energy and nutrients from various agricultural products.

People obtain energy, protein, fat and other nutrients from food, which most agricultural products can provide. Therefore, we believe that the discussion of food safety should not be limited to the supply of cereals, but also should cover the supply of a variety of agricultural products. In addition, to accurately judge whether the supply of agricultural products is sufficient, it is important to combine the food supply with the consumption of food by the population. Therefore, agricultural production should be measured by the population whose energy and nutrients requirements can be met from both vegetable and animal products, produced within a certain period. Furthermore, in the era of economic globalization, it is no longer realistic to reject the international trade of agricultural products and feed a population depended only on domestic agricultural production. Therefore, to determine the degree of China's dependence on foreign agricultural resources, China's agricultural support capacity should be combined with worldwide resources. In addition, to more accurately understand China's national conditions and to better answer the question put forward by Brown in 1994, it is necessary to use the population that can be fed by China's domestic agricultural resources as a reference.

In this article, we discuss China's agricultural support capacity combined with the aforementioned points. Our research objectives were to: 1) propose a concept of agricultural support capacity, and establish a set of models to measure this; 2) analyze China's agricultural support capacity and how this changes under self-sufficiency and open conditions; and 3) measure the degrees of external dependence of China's agricultural support capacity. We hope to accurately answer "who will feed China?" and to evaluate "whether or not the Chinese people can feed themselves?" 


\section{Research Ideas and Methodology}

Energy, protein and fat in food are essential nutrition elements for human physiology, and can satisfy the bodies energy demands, assist in maintaining normal growth and development, and are important for the repair of damaged tissue. Thus, nutrients from food are essential for healthy and survival, of which agricultural products are major food sources. Each type of agricultural product contains the energy, protein and fat required by the human body, however, the quantity and quality differs between products.

Whether the food supply is sufficiently depends not only on agricultural production, but also on population consumed food. Therefore, we propose that food supply should be combined with population consumed food, using the agricultural support capacity to measure the capacity of agriculture to meet the nation's demand, which is more compatible with agricultural requirements, particularly as the basic function of agriculture is to feed people.

\subsection{Supply of Agricultural Products and Food in a Country}

Under self-sufficiency conditions, assuming neither import nor export, i.e. not using foreign resources nor exporting own resources, whereby the production of agricultural products is entirely dependent on a country's own resources, the supply of agricultural products $\left(M_{\text {Domestic }}\right)$ in a country depends only on its domestic agricultural yield $\left(M_{\text {Production }}\right)$ and stock changes $\left(M_{\text {stock }}\right)$, namely:

$$
M_{\text {Domestic }}=M_{\text {Production }}-M_{\text {Stock }}
$$

Under open conditions, considering both import and export, i.e. using foreign resources and exporting own resources; the amount of agricultural product supply $\left(M_{\text {supply }}\right)$ in a country depends not only on $M_{\text {Domestic }}$, but also on the amount of import $\left(M_{\text {Import }}\right)$ and export $\left(M_{\text {Export }}\right)$ of agricultural products, namely:

$$
M_{\text {Supply }}=M_{\text {Domestic }}+M_{\text {Import }}-M_{\text {Export }}
$$

The amount of agricultural products that are directly used as food is not simply equal to the supply of agricultural products $\left(M_{\text {Domestic }}\right.$ or $\left.M_{\text {supply }}\right)$ in a country. Agricultural products can not only be directly used as food, but also indirectly used for further agricultural production, such as providing feed for the animal breeding industry $\left(M_{\text {Feed }}\right)$, seeds for reproduction $\left(M_{\text {seed }}\right)$ and raw materials for food and industrial processing $\left(M_{\text {Processing }}\right)$. It is important to note that a proportion of processed food will return to the food chain of humans in the form of food, and therefore, this can also be included in the food supply. In addition, waste and loss $\left(M_{\text {Waste }}\right)$ of agricultural products occurs during storage, transportation and processing, as well as products for other uses $\left(M_{\mathrm{Other}}\right)$. Therefore, the amount of agricultural products finally used as food ( $\left.M_{\text {Food }}\right)$ should exclude sources of indirect use (e.g. feed and seed), sources used in the processing of raw materials and any waste and loss, and should consider other uses from the supply of agricultural products $\left(M_{\text {Domestic }}\right.$ or $\left.M_{\text {supply }}\right)$. Therefore, the amount of food is: 


$$
M_{\text {Food }}=M_{\text {Domestic }}-M_{\text {Feed }}-M_{\text {Seed }}-M_{\text {Processing }}-M_{\text {Waste }}-M_{\text {Other }}
$$

or

$$
M_{\text {Food }}=M_{\text {Supply }}-M_{\text {Feed }}-M_{\text {Seed }}-M_{\text {Processing }}-M_{\text {Waste }}-M_{\text {Other }}
$$

\subsection{Amount of Energy, Protein and Fat from Food}

The amount of energy and nutrients from various foods are complementary, and can be substituted mutually, therefore, the total energy and total nutrients from food is the sum of the energy and nutrients derived from each specific food and processed goods.

In order to understand whether agriculture production in a particular country can support the energy and nutritional requirements of its population, the amount of energy and nutrients from food that could be consumed by population can be estimated:

$$
\begin{aligned}
& A_{e}(t)=A_{e v}(t)+A_{e a}(t)=\sum a_{i} \times M_{i} \\
& A_{p}(t)=A_{p v}(t)+A_{p a}(t)=\sum b_{i} \times M_{i} \\
& A_{f}(t)=A_{f v}(t)+A_{f a}(t)=\sum c_{i} \times M_{i}
\end{aligned}
$$

where $A_{e}(t), A_{p}(t)$ and $A_{f}(t)$ are the total amounts of energy, protein and fat, respectively, from various foods in year $t$ under self-sufficient or open conditions; $A_{e v}(t), A_{p v}(t)$ and $A_{f v}(t)$ are the amounts of energy, protein and fat, respectively, from vegetable foods; $A_{e a}(t), A_{p a}(t)$ and $A_{f a}(t)$ are the amounts of energy, protein and fat, respectively, from animal foods. $M_{i}$ is the amount of the $i$ th food type; $a_{p}$ $b_{i}$ and $c_{i}$ are the contents of energy, protein and fat in per unit of the $i$ th food type, respectively, the values of which are derived from the Food and Agriculture Organization of the United Nations (FAO) [22]; $i=1-10$ indicates vegetable foods, including cereals, starch roots, sugar and sweeteners, pulses, tree nuts, oil crops and vegetable oil, vegetables, fruits, stimulants and spices, and alcoholic beverages, respectively; and $i=11-15$ indicates animal foods, including meats, offal and animal fats, eggs, milk and aquatic products, respectively.

\subsection{Agricultural Support Capacity Measured by the Amount of Energy from Food}

The energy support capacity $P_{e}(t)$ is measured by the population that can be fed by the energy derived from food. And $P_{e}(t)$ is defined as the population that can be fed by total energy from food in year $t$, according to nutritional intake standards, and is calculated by Equation (7):

$$
P_{e}(t)=A_{e}(t) / S_{e}
$$

where $S_{e}$ is the annual energy intake per capita, according to nutritional intake standards. According to China's food and nutrition development outline for 2014 - 2020 [23], the daily energy intake per capita is estimated to be $2200-2300$ kcal by 2020 , i.e. $S_{e}=8.03 \times 10^{5}-8.40 \times 10^{5} \mathrm{kcal} / \mathrm{capita} /$ year .

Because the nutrients in animal foods are quite different to those in vegetable 
foods, the substitution effects are not the same. The estimation of agricultural support capacity of total energy and nutrients from various foods and their reasonable collocation, need to be further studied. In order to ensure sufficient nutrient intake, GOSCPRC [23] proposed a reasonable energy collocation for daily energy intake, where the proportion of energy from cereals is no less than $50 \%$ and energy from fat is no greater than $30 \%$ in the daily energy intake. According to this standard, the support capacity of energy from cereals should be discussed separately, namely:

$$
P_{e c}(t)=A_{e c}(t) / S_{e c}
$$

where $P_{e c}(t)$ is the population that can be fed by energy derived from cereals in year $t, A_{e c}(t)$ is the amount of energy from cereals; and $S_{e c}$ is the annual per capita intake of energy from cereals, according to nutritional intake standards.

$P(t)$ is the actual population in year $t$, and when $P(t)$ is compared with $P_{e}(t)$ and $P_{e c}(t)$, the following relationships can be observed:

$P(t)>P_{e}(t)$ and $P(t)>P_{e c}(t)$ indicates that both the total energy from food and the energy from cereals are insufficient, and consequently, the living standards of all or part of population are reduced.

$P(t)<P_{e}(t)$ but $P(t)>P_{e c}(t)$ indicates that the total energy from food is sufficient, but energy from cereals is insufficient.

$P(t)>P_{e}(t)$ but $P(t)<P_{e c}(t)$ indicates that the total energy from food is insufficient, but energy from cereals is sufficient.

$P(t)<P_{e}(t)$ and $P(t)<P_{e c}(t)$ indicates that both total energy from food and energy from cereals are sufficient, and consequently, living standards are improved.

\subsection{Agricultural Support Capacity Measured by the Amount of Protein and Fat from Food}

Dietary nutrients can be divided into two levels, the nutrient intake level and the quality of nutrients. The former is measured by the amount of energy, protein and fat from food intake and the latter is measured by the structure of nutrient supply. For instance, compared with protein derived from other vegetable foods, protein from animal sources and soybeans, among others, are more suitable for human consumption as they are rich in essential amino acids. Conversely, compared with saturated fatty acids from animal food sources, associated with increased blood cholesterol levels and adverse health effects, unsaturated fatty acids from vegetable foods are more beneficial for human health. Therefore, the agricultural support capacity should still be measured by the protein and fat obtained from food, including the protein support capacity $P_{p}(t)$ and fat support capacity $P_{\AA}(t) . P_{p}(t)$ and $P_{f}(t)$ are defined as the population that can be fed by the total protein and total fat, respectively, from the food produced in year $t$, according to nutritional intake standards, and is calculated according to Equations (9) and (10):

$$
P_{p}(t)=A_{p}(t) / S_{p}
$$




$$
P_{f}(t)=A_{f}(t) / S_{f}
$$

where $S_{p}$ and $S_{f}$ are annual per capita protein and fat intake, respectively, according to nutritional intake standards.

The nutrient intake recommendations proposed by GOSCPRC [23] are intended to ensure sufficient energy and protein intake, to control fat intake, and to maintain intake of the required amounts of vitamins and minerals. The specific goal for per capita daily protein intake is $78 \mathrm{~g}$, i.e. $S_{p}=2.85 \times 10^{4}$ $\mathrm{g} /$ capita/year, in which superior protein sources will account for greater than $45 \%$ of protein intake by 2020 . Moreover, if the proportion of energy from fat is not more than $30 \%$ of the daily per capita energy intake of $2200-2300 \mathrm{kcal}$, considering that fat produces $9 \mathrm{kcal}$ energy per gram, daily per capita fat intake should not exceed $73-77$ g, i.e. $S_{f}=2.68 \times 10^{4}-2.80 \times 10^{4} \mathrm{~g} / \mathrm{capital} /$ year.

As the quality of protein from vegetable foods and animal foods differ, the nutrient goals established by GOSCPRC [23] also provides specific requirements for protein and superior protein, as it is necessary to collocate protein from food in order to ensure a sufficient protein intake. Therefore, based on the protein support capacity, the superior protein support capacity $P_{p s}(t)$ should also be investigated, measured by the amount of superior protein in year $t$, calculated by Equation (11):

$$
P_{p s}(t)=A_{p s}(t) / S_{p s}
$$

where $A_{p s}(t)$ is the amount of superior protein, including protein from animal foods, and some vegetable foods such as soybean, sesame and sunflower seeds; and $S_{p s}$ is the annual superior protein intake per capita, according to nutritional intake standards.

\subsection{Agricultural Support Capacity to Meet Nutritional Requirements}

To meet all nutritional requirements in year $t$, the energy support capacity $P_{e a}(t)$ can be determined by the minimum $P_{e}(t)$ and $P_{e c}(t)$, where $P_{e a}(t)=\min \left[P_{e}(t)\right.$, $\left.P_{e c}(t)\right]$, and the protein support capacity $P_{p a}(t)$ is determined by the minimum $P_{p}(t)$ and $P_{p s}(t)$, where $P_{p a}(t)=\min \left[P_{p}(t), P_{p s}(t)\right]$. Therefore, in order to meet all requirements, the agricultural support capacity $P_{a}(t)$ is determined by the minimum values for $P_{e a}(t), P_{p a}(t)$ and $P_{f}(t)$, where $P_{a}(t)=\min \left[P_{e a}(t), P_{p a}(t), P_{\AA}(t)\right]$.

When the actual population $P(t)$ is compared with $P_{e a}(t), P_{p a}(t)$ and $P_{A}(t)$ in year $t$, the following relationships can be observed:

$P(t)>P_{e a}(t), P(t)>P_{p a}(t)$ and $P(t)>P_{f}(t)$ indicates that none of the energy, protein and fat from the food produced is sufficient to meet the demand of nation according to nutritional intake standards. Consequently, the living standards of all or part of the population is reduced, where at least $\Delta P_{e}(t)=P(t)-$ $P_{e a}(t), \Delta P_{p}(t)=P(t)-P_{p a}(t)$ and $\Delta P_{f}(t)=P(t)-P_{f}(t)$ of the population will be deficient in energy, protein and fat, respectively.

$P(t)<P_{e a}(t), P(t)>P_{p a}(t)$ and $P(t)>P_{f}(t)$ indicates that the energy from the food produced is sufficient for survival of the population, but that protein and 
fat do not completely meet the requirements. Therefore, all or part of the population are unable to obtain sufficient nutritional intake, and at least $\Delta P_{p}(t)$ and $\Delta P_{f}(t)$ of the population will be deficient in protein and fat.

$P(t)<P_{e a}(t), P(t)<P_{A}(t)$ and $P(t)>P_{p a}(t)$ indicates that the energy and fat from the food produced is sufficient to meet the demand of the nation, but the $\Delta P_{p}(t)$ population will be deficient protein.

$P(t)<P_{e a}(t), P(t)<P_{p a}(t)$ and $P(t)<P_{A}(t)$ indicates that the energy, protein and fat from the food produced exceeds the demand of nation, according to nutritional intake standards, with a surplus of food available, thereby improving living standards.

\subsection{Degree of External Dependence on Agricultural Support Capacity}

In this study, the self-support rate of agricultural support capacity $\beta(t)$ is defined as the ratio of the population $P_{d}(t)$ that can be fed by China's domestic agricultural resources, i.e. the agricultural support capacity under self-sufficiency conditions, to the population $P_{o}(t)$ that can be fed by worldwide agricultural resources, i.e. the agricultural support capacity under open conditions, in a particular country in year $t$, and therefore, $\beta(t)=100 \% \times P_{d}(t) / P_{o}(t)$. If $\beta(t)>100 \%$, the agricultural products produced from a country's own resources is sufficient to meet the demand of the nation, and any surplus agricultural products can be exported to deal with oversupply. If $\beta(t)<100 \%$, the agricultural products produced from a country's own resources cannot meet the demand of the nation, and consequently, agricultural products need to be imported from other countries to ameliorate the insufficient agricultural support capacity.

Similarly, we defined the degree of external dependence $D(t)$ of the agricultural support capacity of a country, under open conditions, as the ratio of the population $P_{i n}(t)$ fed by imported foods, which is part of imported agricultural products used as food, to that $P_{o}(t)$ fed by foods under open conditions, i.e. the agricultural support capacity under open conditions, in year $t$, and therefore, $D(t)=100 \% \times P_{\text {in }}(t) / P_{o}(t) . D(t)$ can be used as an important index to determine the richness of agricultural resources of a particular country, and its extent of agricultural openness. Chen and Zhou [16] stated that cereal self-sufficiency rates of lower than $90 \%$ would endanger national food security in China. Similarly, we agree that $D(t) \leq 10 \%$ or $\beta(t) \geq 90 \%$ indicates stronger agricultural support capacity of a country.

$D(t)$ can be further subdivided into the degree of external dependence of the energy support capacity $D_{e}(t)$, protein support capacity $D_{p}(t)$, superior protein support capacity $D_{s p}(t)$ and fat support capacity $D_{f}(t)$, which can be calculated by Equation (12), respectively:

$$
\begin{gathered}
D_{e}(t)=100 \% \times P_{\text {ine }}(t) / P_{e}(t) ; \quad D_{p}(t)=100 \% \times P_{\text {inp }}(t) / P_{p}(t) ; \\
D_{s p}(t)=100 \% \times P_{\text {insp }}(t) / P_{s p}(t) ; \quad D_{f}(t)=100 \% \times P_{\text {inf }}(t) / P_{f}(t)
\end{gathered}
$$

where $P_{\text {ine }}(t), P_{\text {inp }}(t), P_{\text {insp }}(t)$ and $P_{\text {int }}(t)$ are the population that can be fed by 
energy, protein, superior protein and fat, respectively, from imported foods according to nutritional intake standards in year $t$; and $P_{e}(t), P_{p}(t), P_{s p}(t)$ and $P_{f}(t)$ are the population that can be fed by energy, protein, superior protein and fat, respectively, from the available domestic supply of agricultural products under open conditions in year $t$.

\section{Results}

The data regarding population of China and the annual amount of agricultural products, import and export, stock change, food, feed, seed, waste etc. was extracted from the FAO Statistics Database [24]. The content of specific nutritional components for major food types were also extracted from FAO document on Food balance sheets: A handbook [22]. The standards of nutritional intake were collected from the China Food and Nutrition Development Outline (2014 2020) [23].

\subsection{Amount of Nutrients from Food and China's Agricultural Support Capacity under Self-Sufficient Conditions}

The amount of energy, protein and fat from food domestically produced in China, under self-sufficiency conditions, over several representative years were calculated according to Equations (1)-(6), and the results are presented in Table 1.

In the diet, animal-derived foods such as meats, eggs, milk and aquatic products are excellent sources of nutrients and energy, and these can be substituted for each other without primary and secondary distinctions. However, vegetable-derived foods such as cereals, starchy roots, vegetable oils, sugar, vegetables and fruits have different functions. Among vegetable foods, cereals are a major and necessary source of energy for the population, which cannot be completely replaced by vegetables, fruits, vegetable oils or sugar. Therefore, higher energy requirement comes from cereals. Based on a daily per capita energy intake of $2300 \mathrm{kcal}$, in which the energy from cereals is no less than 50\%, energy from fat is no greater than $30 \%$ and protein intake is $78 \mathrm{~g}$, of which superior protein constitutes above $45 \%$ [23]. The population fed by the energy, protein, superior protein and fat from food and energy from cereals, domestically produced in China over several representative years, were calculated by Equations (7)-(11), and the results are shown in Figure 1(a).

Table 1. Amount of energy, protein and fat from food produced in China under self-sufficiency conditions.

\begin{tabular}{ccccccc}
\hline Year & 1961 & 1970 & 1980 & 1990 & 2000 & 2010 \\
\hline Energy $\left(\times 10^{15} \mathrm{kcal}\right)$ & 0.33 & 0.54 & 0.73 & 1.01 & 1.28 & 1.44 \\
Energy from cereals $\left(\times 10^{15} \mathrm{kcal}\right)$ & 0.18 & 0.34 & 0.49 & 0.65 & 0.71 & 0.70 \\
Protein $\left(\times 10^{10} \mathrm{~kg}\right)$ & 0.92 & 1.33 & 1.81 & 2.65 & 3.80 & 4.51 \\
Superior protein $\left(\times 10^{10} \mathrm{~kg}\right)$ & 0.35 & 0.41 & 0.50 & 0.82 & 1.47 & 1.97 \\
Fat $\left(\times 10^{10} \mathrm{~kg}\right)$ & 0.35 & 0.69 & 1.14 & 1.99 & 3.24 & 4.10 \\
\hline
\end{tabular}




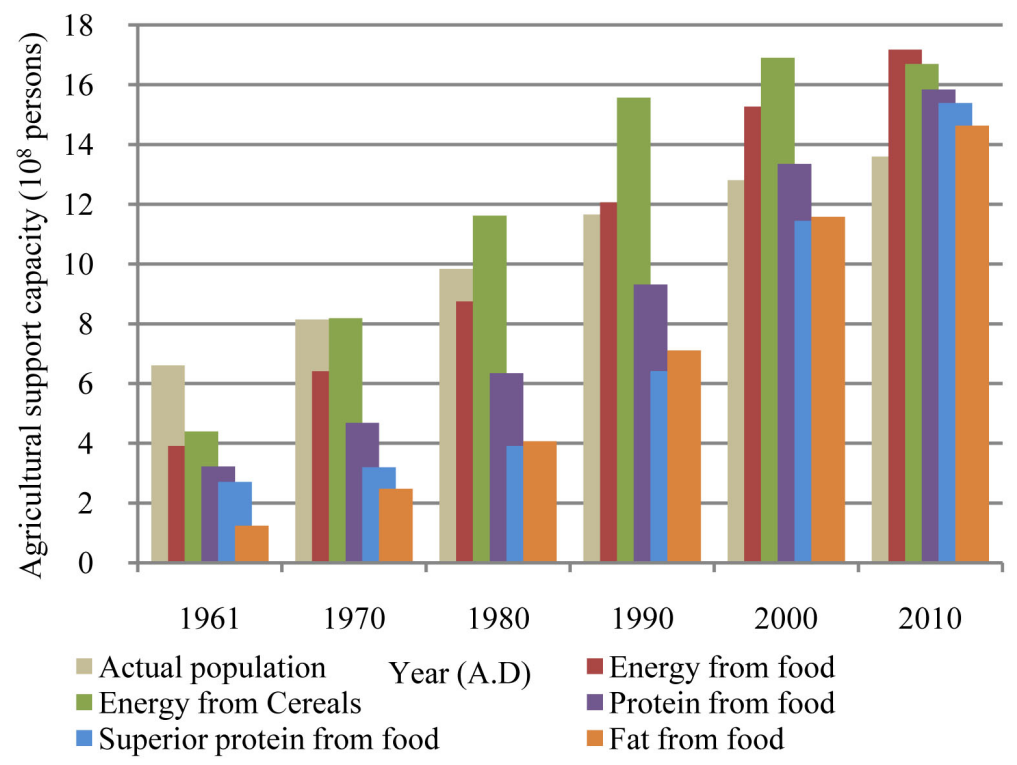

(a)

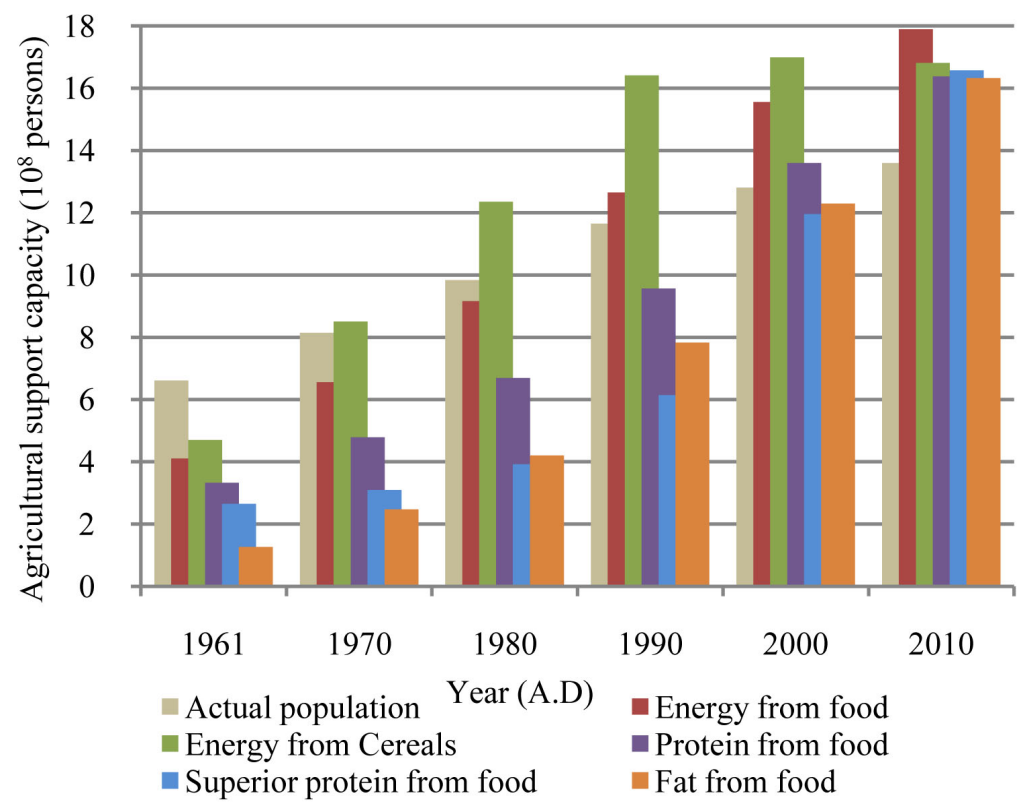

(b)

Figure 1. China's agricultural support capacity. (a) Under self-sufficiency conditions; (b) Under open conditions.

\subsection{Amount of Nutrients Derived from Imported Foods and Exported Agricultural Products and Their Support Capacity}

The amount of energy, protein, superior protein and fat from imported foods and exported agricultural products in China over several representative years, were calculated by Equations (1)-(6), and the results are presented in Table 2. The population fed by the energy, protein, superior protein and fat from imported foods and exported agricultural products were calculated by Equations (7)-(11), and the results are shown in Figure 2. 


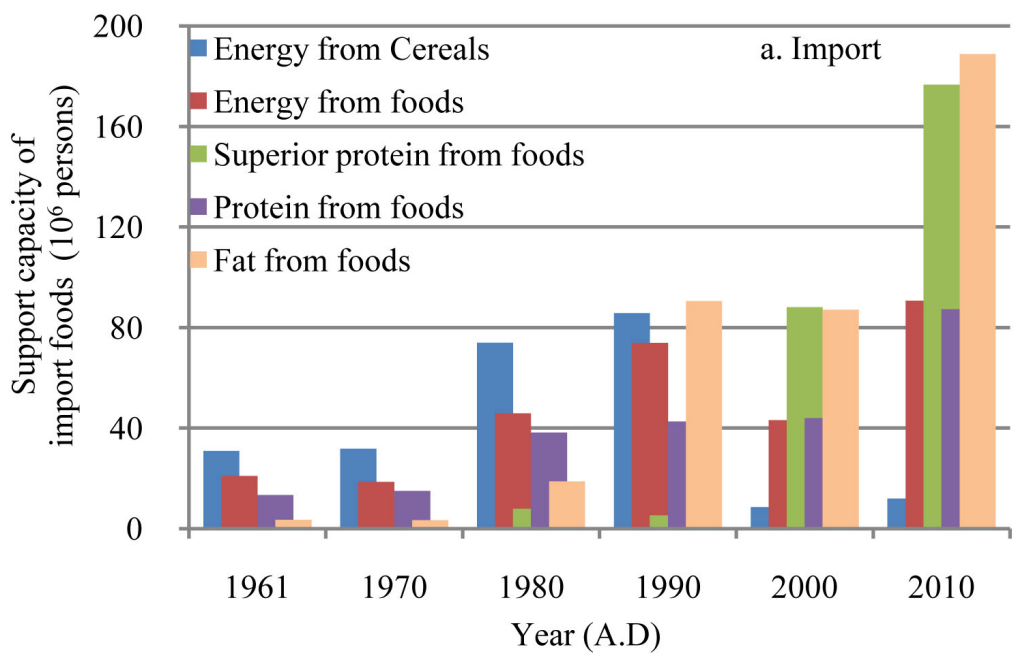

(a)

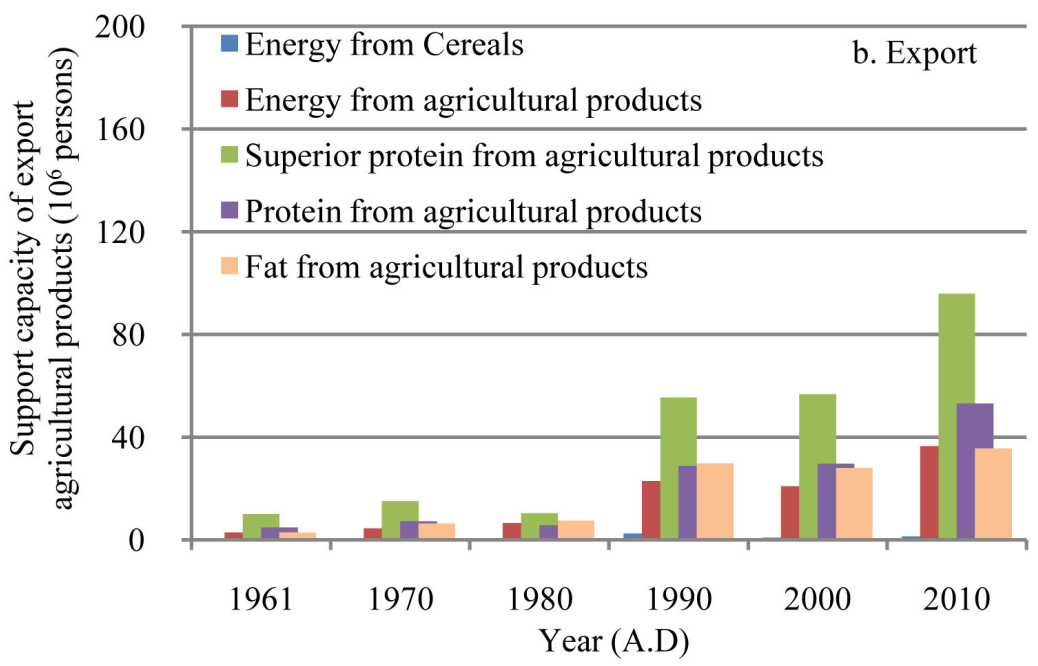

(b)

Figure 2. Support capacity of imported foods and exported agricultural products in China. (a) Import; (b) Export.

Table 2. Amount of energy, protein and fat from imported foods and exported agricultural products in China.

\begin{tabular}{lcccccc}
\hline \multicolumn{1}{c}{ Year } & 1961 & 1970 & 1980 & 1990 & 2000 & 2010 \\
\hline Energy from imported foods $\left(\times 10^{13} \mathrm{kcal}\right)$ & 1.76 & 1.56 & 3.86 & 6.21 & 3.63 & 7.62 \\
Energy from imported cereals $\left(\times 10^{13} \mathrm{kcal}\right)$ & 1.30 & 1.34 & 3.11 & 3.60 & 0.36 & 0.50 \\
Protein from imported foods $\left(\times 10^{8} \mathrm{~kg}\right)$ & 3.85 & 4.30 & 10.89 & 12.15 & 12.54 & 24.88 \\
Superior protein from imported foods $\left(\times 10^{8} \mathrm{~kg}\right)$ & 0.00 & 0.00 & 1.02 & 0.68 & 11.29 & 22.64 \\
Fat from imported foods $\left(\times 10^{8} \mathrm{~kg}\right)$ & 1.01 & 0.95 & 5.28 & 25.37 & 24.38 & 52.86 \\
Energy from exported agricultural products $\left(\times 10^{13} \mathrm{kcal}\right)$ & 0.25 & 0.37 & 0.55 & 1.92 & 1.75 & 3.07 \\
Energy from exported cereals $\left(\times 10^{13} \mathrm{kcal}\right)$ & 0.02 & 0.00 & 0.01 & 0.10 & 0.04 & 0.06 \\
Protein from exported agricultural products $\left(\times 10^{8} \mathrm{~kg}\right)$ & 1.38 & 2.09 & 1.65 & 8.19 & 8.45 & 15.15 \\
Superior protein from exported agricultural products & 1.30 & 1.93 & 1.34 & 7.12 & 7.27 & 12.29 \\
$\left(\times 10^{8} \mathrm{~kg}\right)$ & & & & & & \\
Fat from exported agricultural products $\left(\times 10^{8} \mathrm{~kg}\right)$ & 0.82 & 1.78 & 2.10 & 8.34 & 7.86 & 9.99 \\
\hline
\end{tabular}




\subsection{Amount of Nutrients from Food and China's Agricultural Support Capacity under Open Conditions}

The amount of energy, protein, superior protein and fat from foods under open conditions over several representative years were calculated by Equations (1)-(6), and the results are presented in Table 3. The population that can be fed with this amount of energy, protein, superior protein and fat was calculated by Equations (7)-(11), and the results are shown in Figure 1(b).

\subsection{Degree of External Dependence of China's Agricultural Support Capacity}

The degree of external dependence of the energy, protein and fat support capacity between 1961 and 2013 were calculated by Equation (12), and the results are shown in Figure 3.

\section{Discussion}

\subsection{Changes in the Agricultural Support Capacity of China under Self-Sufficient Conditions}

In 1961, due to overstress crop-plantation at the expense of the animal breeding industry, there was insufficient energy available from food and cereals domestically produced in China, resulting in $2.70 \times 10^{8}$ and $2.21 \times 10^{8}$ people that were unable to obtain sufficient energy from food and cereals, respectively, as shown in

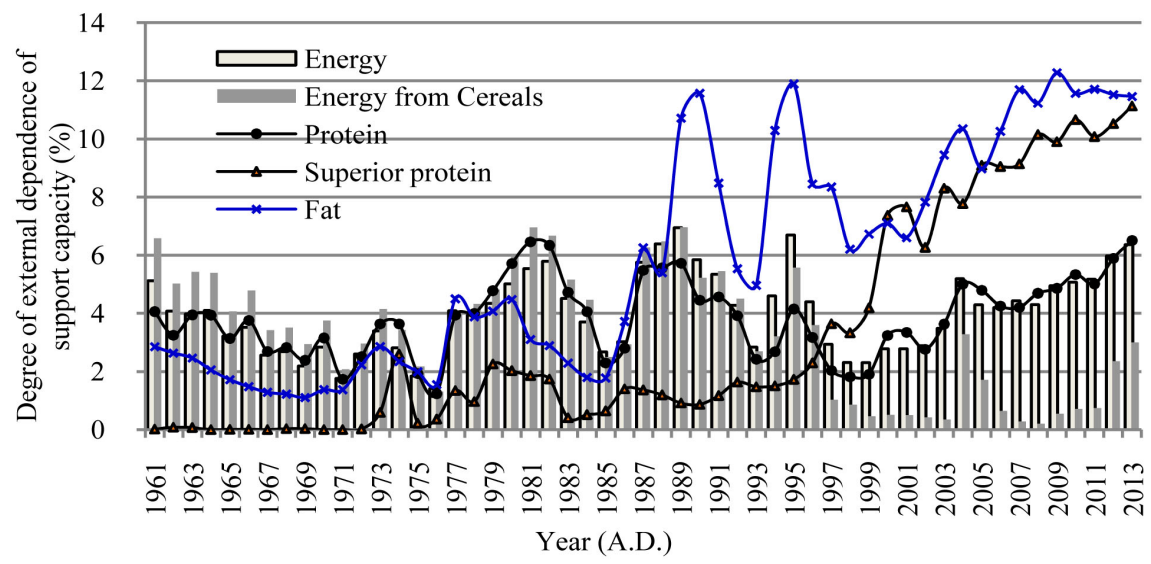

Figure 3. Degree of external dependence of China's agricultural support capacity.

Table 3. Amount of energy, protein and fat from foods produced in China under open conditions.

\begin{tabular}{ccccccc}
\hline Year & 1961 & 1970 & 1980 & 1990 & 2000 & 2010 \\
\hline Energy $\left(\times 10^{15} \mathrm{kcal}\right)$ & 0.34 & 0.55 & 0.77 & 1.06 & 1.31 & 1.50 \\
Energy from cereals $\left(\times 10^{15} \mathrm{kcal}\right)$ & 0.20 & 0.36 & 0.52 & 0.69 & 0.71 & 0.71 \\
Protein $\left(\times 10^{10} \mathrm{~kg}\right)$ & 0.95 & 1.36 & 1.90 & 2.73 & 3.87 & 4.66 \\
Superior protein $\left(\times 10^{10} \mathrm{~kg}\right)$ & 0.34 & 0.40 & 0.50 & 0.79 & 1.53 & 2.12 \\
Fat $\left(\times 10^{10} \mathrm{~kg}\right)$ & 0.35 & 0.69 & 1.14 & 1.99 & 3.24 & 4.10 \\
\hline
\end{tabular}


Figure 1(a). The lack of energy from cereals observed in 1961 continued until the 1970s. In 1978, the introduction of agricultural reform and implementation of opening to the outside world and the household contract responsibility system for farmland improved the production enthusiasm and independence of farmers. Since then, China's agricultural output has greatly improved, and the total energy provided by domestically produced foods and cereals has continually increased. After 1990, the total energy from foods and cereals has been sufficient to meet the nation's demand.

However, between 1961 and 1997, under self-sufficient conditions, the amount of protein from food, particularly the superior protein, was unable to meet the nutritional requirements of the actual population. In 1961, the population that lacked protein and superior protein was $3.38 \times 10^{8}$ and $3.91 \times 10^{8}$ people, respectively, and in 1977, the population lacked superior protein increased to $6.13 \times 10^{8}$ people, accounting for $64.93 \%$ of the total population. Between 1977 and 1997, the amount of protein and superior protein provided by domestic production has increased greatly, and the gap between the demand for protein and its supply from domestic production had decreased, however, demand for nutrients could not be met completely during this time due to population growth and an improvement in living standards. Therefore, in 1997, $0.10 \times$ $10^{8}$ and $1.91 \times 10^{8}$ people still lacked sufficient dietary protein and superior protein, respectively. Between 1998 and 2013, the area of pulse sown decreased at an average annual rate of $1.56 \%$, and consequently, pulse output decreased at an average annual rate of $1.57 \%$ from $1.52 \times 10^{10} \mathrm{~kg}$ in 1998 to only $1.20 \times 10^{10} \mathrm{~kg}$ in 2013 [25]. This led to an insufficient supply of superior protein from vegetable foods. In contrast, animal foods outputs, including meats, eggs and milk grew rapidly over the same period, with average annual rates of $3.73 \%, 3.47 \%$ and $10.31 \%$, respectively. Since 2007 , superior protein provided by domestic production has not only been able to feed the population, but has also been produced in surplus, as superior protein produced domestically could feed $1.79 \times 10^{8}$ more people than the actual population in 2010.

Similar to protein, under self-sufficiency conditions, from 1961 to 2006, the amount of fat from food was also unable to meet the nutritional requirements of the population under self-sufficiency conditions. Furthermore, the gap between the demand for fat and its supply from domestic production continually increased between 1966 and 1977, however, the gap began to narrow after 1978. In $1961,1970,1980,1990$ and 2000 there were $5.37 \times 10^{8}, 5.66 \times 10^{8}, 5.77 \times 10^{8}$, $4.54 \times 10^{8}$ and $1.22 \times 10^{8}$ people, respectively, lacking in an adequate amount fat from food, and therefore, China had to rely on imported foods to meet these demands. After 2007, the amount of fat from domestically produced food was able to feed the population, and in 2010 this was in oversupply, and could feed $1.04 \times 10^{8}$ more people than the actual population.

In summary, energy from cereals, total energy, and the amount of protein, superior protein and fat provided by domestic production in China has been able to feed the population since 1970, 1990, 1998, 2007 and 2007, respectively. 


\subsection{Changes in Support Capacity of Imported Food and Exported Agricultural Products}

In China, a great deal of cereals was imported before 1990, which increased the energy supply. After 1990, a great deal of foods being rich in protein and fat, such as soybeans and vegetable oils, was imported, which improved the nutrient supply.

Prior to 1990, most of the energy provided by imported food came from cereals. Therefore, imported cereals made a greater contribution to the improvement of the China's agricultural support capacity at this time, which quickly fell after 1990. Between 1961 and 2013, although the proportion of imported cereals to available domestic cereals was low, the imported amount remained high. For example, the average annual amount of imported cereals was $7.8 \times 10^{9} \mathrm{~kg}$, in which the amount of imported cereals used as food was $4.29 \times 10^{9}, 4.23 \times 10^{9}$, $9.83 \times 10^{9}, 11.43 \times 10^{9}, 1.14 \times 10^{9}$ and $1.58 \times 10^{9} \mathrm{~kg}$ in $1961,1970,1980,1990$, 2000 and 2010, respectively. Therefore, the energy provided by imported cereals was high during this period (Table 2). Between 1961 and 1990, the average annual energy from imported cereals was $2.07 \times 10^{13} \mathrm{kcal}$, and the proportion of energy from cereals to overall energy from imported food was $76.37 \%$, which decreased continually after 1990. From 1991 to 2000, the average annual energy from imported cereals was $1.93 \times 10^{13} \mathrm{kcal}$ and the proportion of energy from cereal to overall energy from imported food dropped to $39.09 \%$. Both the amount of imported cereals and the proportion of energy decreased after 2000, with an average annual proportion of only 9.98\% from 2001 to 2010 .

Between 1961 and 1996, an average annual proportion of energy from imported soybeans was only $0.75 \%$ of all imported food. China has rapidly increased its net import of soybeans since 1996, and the amount of imported soybeans and the proportion of energy from those increased rapidly from 1997. For instance, the amount of imported soybeans used as food in 1997 was $1.11 \times 10^{9}$ $\mathrm{kg}$, which provided $0.39 \times 10^{13} \mathrm{kcal}$ energy and accounted for $10.67 \%$ of total energy from imported food, whereas in 2000 and 2010 the amount had increased to $2.07 \times 10^{9}$ and $4.54 \times 10^{9} \mathrm{~kg}$, respectively, providing $0.72 \times 10^{13}$ and $1.58 \times 10^{13}$ kcal energy and accounting for 19.92 and 20.97\%, respectively. Similarly, in 1985 the proportion of energy from imported vegetable oils was only $4.23 \%$, but the amount of imported vegetable oils and the proportion of energy from those increased rapidly after 1986 , with $1.43 \times 10^{9}$ and $3.89 \times 10^{9} \mathrm{~kg}$ imported in 2000 and 2010 , respectively, providing $1.25 \times 10^{13}$ and $3.43 \times 10^{13} \mathrm{kcal}$ energy and accounting for 34.51 and $45.07 \%$, respectively.

Before 1995, the amount of protein provided by imported foods mainly came from cereals. In 1961, the proportion of protein from imported cereals reached 99.26\%, with an average annual proportion of 93.27\% observed between 1961 and 1995. After 1995, the proportion rapidly fell to an average annual proportion of only $15.33 \%$ observed between 1996 and 2013. Since 1996, soybeans and aquatic products have become the most highly imported protein sources, with the proportion of protein increasing from $12.07 \%$ and $8.91 \%$, respectively, in 
1996, to $59.81 \%$ and $13.40 \%$, respectively, in 2010.

Similar to protein, the major source of fat from imported foods before 1984 was cereals, followed by vegetable oils and animal fats, with an average annual proportion of fat supplied by these imported foods being 49.65, 27.23 and $17.65 \%$, respectively, observed between 1961 and 1984. Since 1985, vegetable oils and soybeans have become the major sources of fat in imported foods. The proportion of fat from imported vegetable oils has grown steadily, with an average annual proportion of $74.49 \%$ observed between 1985 and 2013. In 2010, the amount of dietary fat provided by imported cereals, soybeans and vegetable oils accounted for $0.43 \%, 10.10 \%$ and $73.95 \%$ of fat from imported food, respectively.

Although the proportion of the population fed by energy from imported cereals has decreased, the population fed by energy, protein and fat from other imported foods has increased (Figure 2(a)). In 1961, the population fed by the energy, protein and fat from imported foods was $2.10 \times 10^{7}, 1.35 \times 10^{7}$ and 0.36 $\times 10^{7}$ people, respectively, which had increased to $9.07 \times 10^{7}, 8.74 \times 10^{7}$ and $18.88 \times 10^{7}$ people, respectively, in 2010. After 2000, superior protein from imported foods has greatly increased China's superior protein support capacity, which could meet the requirements of $8.81 \times 10^{7}$ and $17.67 \times 10^{7}$ people in 2000 and 2010 , respectively.

With the exception of few foods, such as beans, vegetables, fruits and eggs, the amount of exported agricultural products was much lower than the imported amount, and therefore, the exported energy, protein and fat from agricultural products was low (Table 2). However, the exported amount of energy and protein from agricultural products increased. This led to an increase in the population able to be fed by the exported agricultural products (Figure $2(\mathrm{~b})$ ), with the population fed by the energy, protein, superior protein and fat from exported agricultural products increasing from $0.30 \times 10^{7}, 0.49 \times 10^{7}, 1.01 \times 10^{7}$ and 0.29 $\times 10^{7}$ people, respectively, in 1961 , to $3.65 \times 10^{7}, 5.32 \times 10^{7}, 9.60 \times 10^{7}$ and $3.57 \times$ $10^{7}$ people, respectively, in 2010.

Prior to 1983, when import was compared with export, the main imported agricultural products were vegetable products, while the main export products were animal products. The ratio of energy from imported cereals to exported cereals fell sharply, from 65.70 in 1961 to 34.66 in 1990, with a ratio of only 8.75 in 2010. Conversely, superior protein and fat from imported foods grew more rapidly than exported agricultural products, with the ratios of imported to exported superior protein and fat increasing from 0.003 and 1.22 in 1961, 0.10 and 3.04 in 1990, to 1.84 and 5.29, respectively in 2010 .

Although there was a net export of protein in 1985-1986, 1994, 1999 and 2002, superior protein from 1961 to 1999, and fat in 1964-1972, 1974-1976 and 1983-1986, the net import of energy, protein, superior protein and fat continually increased during the other years. The exported animal products from China in 1990 was rich in superior protein, in which the export of bovine meat was $2.16 \times 10^{8} \mathrm{~kg}$, pig meat was $2.36 \times 10^{8} \mathrm{~kg}$, poultry meat was $4.6 \times 10^{7} \mathrm{~kg}$, other meats were $3.8 \times 10^{7} \mathrm{~kg}$, eggs were $4.1 \times 10^{7} \mathrm{~kg}$ and the export of pelagic 
fish and marine fish, crustaceans and molluscs was $5.32 \times 10^{8} \mathrm{~kg}$ [24]. The net superior protein from exported vegetable and animal products in the same year was $5.29 \times 10^{8} \mathrm{~kg}$, which was sufficient to meet the superior protein requirement of $4.1 \times 10^{7}$ people. By 2000 , the net imported superior protein was $4.02 \times 10^{8} \mathrm{~kg}$. Furthermore, a large amount of peas, soybeans and sesame seeds were imported in 2010, in which the soybeans import was 3.63 times of domestic production. The net import of peas, soybeans and sesame seeds was $2.18 \times 10^{8}, 4.32 \times 10^{9}$ and $1.41 \times 10^{8} \mathrm{~kg}$, respectively, providing the total amount of superior protein of $1.49 \times 10^{9} \mathrm{~kg}$, which could meet the demands of $1.16 \times 10^{8}$ people. The net import of agricultural products could meet the energy, protein, superior protein and fat requirements of $0.54 \times 10^{8}, 0.34 \times 10^{8}, 0.81 \times 10^{8}$ and $1.53 \times 10^{8}$ people, respectively.

\subsection{Changes in Agricultural Support Capacity of China under Open Conditions}

As shown in Figure 1(b), energy from cereals, as well as total energy, protein, superior protein and fat from food, increased in most years under open conditions.

In 1961 there was a serious shortage in agricultural product supply in China, with much lower import and export of agricultural products, and consequently, demand for food exceeded supply. The amount of food was unable to meet the energy and nutrients requirement of the Chinese, with $1.91 \times 10^{8}, 2.51 \times 10^{8}$, $3.28 \times 10^{8}, 3.96 \times 10^{8}$ and $5.35 \times 10^{8}$ people lacking of the energy from cereals, total energy, protein, superior protein and fat, respectively. At that time, due to the lack of energy and nutrients, malnutrition was the major the national health problem.

With development and adjustment of the agricultural structure, energy from vegetable and animal products has increased rapidly. Since 1970, demand for energy from cereals has been met, and total energy from food has been met since 1982, both produced in surplus. Furthermore, after 1982 the number of people that could be fed by the total energy from food has exceeded the actual population. However, after many years of food restriction, the Chinese diet had changed to consist of more cereals and fewer animal products and beans.

After opening to the outside world, the gaps between the demand for and supply of protein, superior protein and fat have reduced, and the undernourished proportion of the population decreased. Between 1961 to 1990, the protein and superior protein from food could not meet demand, and the proportion of the population that did not consume adequate levels of protein in 1961, 1970, 1980 and 1990 was $49.60 \%, 41.19 \%, 32.02 \%$ and $17.86 \%\left(3.28 \times 10^{8}, 3.35 \times 10^{8}\right.$, $3.15 \times 10^{8}$ and $2.08 \times 10^{8}$ people), respectively, and the proportion of the population that were deficient in superior protein was $59.90 \%, 61.97 \%, 60.15 \%$ and $47.28 \%\left(3.96 \times 10^{8}, 5.05 \times 10^{8}, 5.92 \times 10^{8}\right.$ and $5.51 \times 10^{8}$ people $)$, respectively. Because of this, many people had to survive on a lower nutritional level by tightening their belts. In 2000, the amount of protein from food was in surplus, and 
could feed $0.79 \times 10^{8}$ more people than the actual population. However, in the same year, $0.85 \times 10^{8}$ people were still deficient in their superior protein intake. By 2010 , both protein and superior protein from food were in surplus, and could feed $2.78 \times 10^{8}$ and $2.98 \times 10^{8}$ more people, respectively, than the actual population.

Similar to protein, after 2003 the amount of fat from food was able to meet the nutritional requirements of the Chinese, with a surplus that could feed $7.46 \times 10^{6}$ more people than the actual population in 2003.

In summary, as shown in Figure 1, opening to the outside world has improved China's agricultural support capacity. For instance, compared open conditions in 2010 with self-sufficient conditions, the support capacities of energy from cereals, total energy, protein, superior protein and fat increased by $0.68 \%$, $4.17 \%, 3.39 \%, 7.73 \%$ and $11.51 \%$, respectively.

\subsection{Changes in the Degree of External Dependence of China's Agricultural Support Capacity}

As shown in Figure 3, based on the agricultural support capacity, measured by the energy, protein and fat, the external dependence of China's agricultural support capacity had been very low between 1961 and 1985, with average annual degrees of external dependences of only $3.51 \%, 3.60 \%$ and $2.37 \%$, respectively. However, over the past two decades (1986-2013), the external dependence of the protein, superior protein and fat support capacity has increased at average annual rates of $3.16 \%, 7.99 \%, 4.26 \%$, with average annual degrees of external dependence of $4.08 \%, 5.49 \%$ and $8.95 \%$, respectively.

The degree of external dependence of the support capacity of energy from cereals was rather low from 1961 to 2013, with an average annual degree of external dependence of $3.33 \%$, the lowest of which was $0.20 \%$ and the highest was $6.96 \%$, it indicates a stronger self-support capacity of energy from cereals in China. In contrast, the change in the degree of external dependence of the superior protein support capacity was significant, as an average annual degree of external dependence was lower than $0.10 \%$ before 1972, but grew slowly from 1973 to 1995 at an average annual rate of $5.01 \%$, with a maximum degree of external dependence of $1.73 \%$. This increased rapidly from 1996 to 2013 at an average annual rate of $9.74 \%$, and was greater than $10 \%$ after 2008 . Similar to superior protein, change in the degree of external dependence of the fat support capacity was also significant, which was lower between 1961 and 1986 with an average annual of $2.42 \%$, and continued to increase at an average annual rate of $2.36 \%$ between 1987 and 2013 with an average annual of 9.14\%, and was greater than $10 \%$ after 2004 and reached to $11.46 \%$ in 2013. In summary, the degree of external dependence of the superior protein and fat support capacity after 2008 and 2004, respectively, have been too high, and were over the national food security warning level. This indicates that China's agriculture support capacity, measured by the superior protein and fat, is strongly dependent on worldwide resources, 
and that the structure of China's agricultural products is not reasonable, over the past 10 years.

\section{Conclusions}

- China has been achieved self-sufficiency for cereals since 1970. The degree of external dependence of the support capacity of energy from cereals was relatively low between 1961 and 2013, with an average annual of 2.91\%, which indicates a stronger self-support capacity of energy from cereals in China. China imports various cereals every year to improve food diversity and to provide feed for the animal breeding industry.

- Since 2007, the energy, protein, superior protein and fat provided by domestically produced food has been sufficient to feed the Chinese population, and there has even been surplus. In 2010, China had an actual population of 13.60 $\times 10^{8}$, and even without foreign resources, the energy provided by China's agricultural products could feed $17.18 \times 10^{8}$ people.

- Before 2007, the demand for the protein, superior protein and fat, based only on domestically produced food, was not completely met. As a result, the Chinese had to survive on the lower nutritional levels, or to rely on the net import of agricultural products to meet these nutritional requirements. China's agricultural product trade has been characterized by a higher import to export ratio, particularly over the past ten years, and the degree of external dependence of the superior protein and fat support capacity were too high and greater than the national food security warning level, which reached $11.13 \%$ and $11.46 \%$, respectively, in 2013 . This indicates that China's agricultural support capacity, as measured by the superior protein and fat, is strongly dependent on worldwide resources, and that the structure of China's agricultural products is not reasonable.

- Compared open conditions in 2010 with self-sufficient conditions, the actual support capacities of the energy from cereals, total energy, protein, superior protein and fat from food in China increased by $0.68 \%, 4.17 \%, 3.39 \%, 7.73 \%$ and $11.51 \%$, respectively. Opening to the outside world has strengthened China's agricultural support capacity and helped meet the needs for domestic food diversity, in addition to regulating food surpluses and deficiencies.

\section{Acknowledgements}

This work was supported by the Natural Science Foundation of China (NSFC, NO. 41271467).

\section{References}

[1] Brown, L.R. (1994) Who Will Feed China? World Watch, 9, 10-19.

[2] IOSCPRC (Information Office of the State Council of the People's Republic of China) (2001) The Grain Issue in China. Foreign Languages Press, Beijing.

[3] NDRC (National Development and Reform Commission) (2008) National Food 
Security and Long-Term Planning Framework (2008-2020). http://www.gov.cn/jrzg/2008-11/13/content_1148414.htm

[4] Cao, M., Ma, S. and Han, C. (1995) Potential Productivity and Human Carrying Capacity of an Agro-Ecosystem: An Analysis of Food Production Potential of China. Agricultural Systems, 47, 387-414. https://doi.org/10.1016/0308-521X(95)92106-G

[5] Song, W. and Pijanowski, B.C. (2014) The Effects of China's Cultivated Land Balance Program on Potential Land Productivity at a National Scale. Applied Geography, 46, 158-170. https://doi.org/10.1016/j.apgeog.2013.11.009

[6] Tao, F., Zhang, S., Zhang, Z. and Rötter, R.P. (2015). Temporal and Spatial Changes of Maize Yield Potentials and Yield Gaps in the Past Three Decades in China. Agriculture, Ecosystems and Environment, 208, 12-20. https://doi.org/10.1016/j.agee.2015.04.020

[7] Yang, H. and Li, X. (2000) Cultivated Land and Food Supply in China. Land Use Policy, 17, 73-88. https://doi.org/10.1016/S0264-8377(00)00008-9

[8] CNS (Chinese Nutrition Society) (2008) Chinese Resident Meals Guide. Tibet People's Press, Tibet.

[9] CNS (Chinese Nutrition Society) (2014) Chinese Dietary Guidelines (2013). Science Press, Beijing.

[10] Fan, S. and Brzeska, J. (2014) Feeding More People on an Increasingly Fragile Planet: China's Food and Nutrition Security in a National and Global Context. Journal of Integrative Agriculture, 13, 1193-1205. https://doi.org/10.1016/S2095-3119(14)60753-X

[11] Goggins, G. and Rau, H. (2015) Beyond Calorie Counting: Assessing the Sustainability of Food Provided for Public Consumption. Journal of Cleaner Production, 44, $1-10$.

[12] Li, G., Zhao, Y. and Cui, S. (2013) Effects of Urbanization on Arable Land Requirements in China, Based on Food Consumption Patterns. Food Security, 5, 439-449. https://doi.org/10.1007/s12571-013-0265-9

[13] MAPRC (Ministry of Agriculture of the People's Republic of China) (2004) Outline for the Development of Food and Nutrition in China (2001-2010). Acta Nutrimenta Sinica, 4, 337-341.

[14] Rozelle, S. and Rosegrant, M.W. (1997) China's Past, Present, and Future Food Economy: Can China Continue to Meet the Challenges? Food Policy, 22, 191-200. https://doi.org/10.1016/S0306-9192(97)00024-9

[15] Xu, S.W., Li, G.Q. and Li, Z.M. (2015) China Agricultural Outlook for 2015-2024 Based on China Agricultural Monitoring and Early-warning System (CAMES). Journal of Integrative Agriculture, 14, 1889-1902. https://doi.org/10.1016/S2095-3119(15)61149-2

[16] Chen, B.M. and Zhou, X.P. (2005) Analysis on the Grain Self-Sufficient Ratio and the Safe Baseline of Cultivated Land in China. Economic Geography, 25, 145-148.

[17] Rask, K. and Rask, N. (2004) Reaching Turning Points in Economic Transition: Adjustments to Distortions in Resource-Based Consumption of Food. Comparative Economic Studies, 46, 542-569. https://doi.org/10.1057/palgrave.ces.8100050

[18] Rask, K. and Rask, N. (2011) Economic Development and Food Production-Consumption Balance: A Growing Global Challenge. Food Policy, 36, 186-196. https://doi.org/10.1016/j.foodpol.2010.11.015

[19] Ali Hassan, H.B., Awad Zaghloul, E., El-Gebaly, M.R. and Hussein, Y.M.M. (2013) An Economic Study of the Most Important Oilseed Crops in Egypt. Nature and 
Science, 11, 201-209.

[20] Bishwajit, G., Sarker, S., Kpoghomou, M.A., Gao, H., Jun, L., Yin, D.G., et al. (2013) Self-Sufficiency in Rice and Food Security: A South Asian Perspective. Agriculture \& Food Security, 2, 10. https://doi.org/10.1186/2048-7010-2-10

[21] Yoshii, K. and Oyama, T. (2016) A Quantitative Factorial Component Analysis to Investigate the Recent Changes of Japan's Weight-Based Food Self-Sufficiency Ratio. American Journal of Operations Research, 6, 44-60. https://doi.org/10.4236/ajor.2016.61007

[22] FAO (Food and Agricultural Organization of the United Nations) (2001) Food Balance Sheets: A Handbook.

[23] GOSCPRC (General Office of the State Council of the People's Republic of China) (2014) China Food and Nutrition Development Outline (2014-2020). http://www.gov.cn/xxgk/pub/govpublic/mrlm/201402/t20140208_66624.html

[24] FAO (Food and Agriculture Organization of the United Nations) (2016) 2013 Food Balance Sheets for 42 Selected Countries (and Updated Regional Aggregates). http://faostat3.fao.org/download/FB/FBS/E

[25] NBSPRC (National Bureau of Statistics of the People's Republic of China) (2015) China Statistic Yearbook 2015. China Statistics Press, Beijing. 